\title{
Tying Requirements in Markets with Many Sellers: The Contact Lens Industry
}

Deborah Haas-Wilson

Smith College, dhwilson@smith.edu

Follow this and additional works at: https://scholarworks.smith.edu/eco_facpubs

Part of the Economics Commons

\section{Recommended Citation}

Haas-Wilson, Deborah, "Tying Requirements in Markets with Many Sellers: The Contact Lens Industry" (1987). Economics: Faculty Publications, Smith College, Northampton, MA.

https://scholarworks.smith.edu/eco_facpubs/7 
Tying Requirements in Markets with Many Sellers: The Contact Lens Industry Author(s): Deborah Haas-Wilson

Source: The Review of Economics and Statistics, Vol. 69, No. 1 (Feb., 1987), pp. 170-175 Published by: The MIT Press

Stable URL: https://www.jstor.org/stable/1937918

Accessed: 05-03-2019 16:55 UTC

JSTOR is a not-for-profit service that helps scholars, researchers, and students discover, use, and build upon a wide range of content in a trusted digital archive. We use information technology and tools to increase productivity and facilitate new forms of scholarship. For more information about JSTOR, please contact support@jstor.org.

Your use of the JSTOR archive indicates your acceptance of the Terms \& Conditions of Use, available at https://about.jstor.org/terms 
The hypothesis that $\operatorname{var}(e)$ was constant across states would be rejected at the 0.05 level for the independent agency sample using a likelihood ratio test. It would not be rejected at the 0.10 level for the direct writers.

For the independent agency insurers, $\hat{b}_{1 i}$ ranged from -0.008 to 0.149 . The range for direct writers was 0.020 to $0.049 .{ }^{14}$ The five states with the largest weightedaverage (by premiums) $\hat{b}_{1 i} \mathrm{~s}$ for the groups (in parentheses) were New Hampshire (0.111), New Jersey (0.068), North Carolina (0.061), Rhode Island (0.059), and Maine $(0.055)$. The five states with the smallest values were Tennessee (0.007), Arkansas (0.013), New York (0.022), Nebraska (0.022), and Iowa (0.025). Research is needed to explain this variation. It also would be desirable to estimate the effect of rate regulation on expected losses, to examine potential differences in its impact across consumer groups, and to investigate nonprice responses to restrictive rate regulation in this market.

\section{REFERENCES}

D’Arcy, Stephen, “An Economic Theory of Insurance Regulation," Ph.D. dissertation, University of Illinois, 1982.

Grabowski, Henry, W. Kip Viscusi, and William Evans, "The Effects of Regulation on the Price and Availability of Automobile Insurance," paper presented at Nineteenth International Atlantic Economic Conference, Rome, Italy, March 1985.

${ }^{14}$ The correlation between the estimates for the groups was
0.75 .
Griffiths, William, "Estimation of Actual Response Coefficients in the Hildreth-Houck Random Coefficient Model," Journal of the American Statistical Association 67 (Sept. 1972), 633-635.

Harrington, Scott, "Estimating the Impact of Prior Approval Regulation on Auto Insurance Rates," Working Paper No. 84-3, Center for Research on Risk and Insurance, University of Pennsylvania, July 1984a.

, "The Impact of Rate Regulation on Prices and Underwriting Results in the Property-Liability Insurance Industry: A Survey," Journal of Risk and Insurance 51 (Dec. 1984b), 577-623.

Ippolito, Richard, "The Effects of Price Regulation in the Automobile Insurance Industry," Journal of Law and Economics 22 (Apr. 1979), 55-89.

Joskow, Paul, "Cartels, Competition and Regulation in the Property-Liability Insurance Industry,” Bell Journal of Economics and Management Science 4 (Autumn 1973), 375-427.

" "Inflation and Environmental Concern: Structural Change in the Process of Public Utility Price Regulation," Journal of Law and Economics 17 (Oct. 1974), 291-327.

Pauly, Mark, Paul Kleindorfer, and Howard Kunreuther, "Regulation and Quality Competition in the U.S. Insurance Industry," in J. Finsinger and M. Pauly (eds.), The Economics of Insurance Regulation (London: Macmillan Press, 1986).

Smallwood, Dennis, "Competition, Regulation, and Product Quality in the Automobile Insurance Industry," in Almarin Phillips (ed.), Promoting Competition in Regulated Markets (Washington, D.C.: The Brookings Institution, 1975).

U.S. General Accounting Office, Issues and Needed Improvements in State Regulation of the Insurance Business (Washington, D.C.: U.S. General Accounting Office, 1979).

\title{
TYING REQUIREMENTS IN MARKETS WITH MANY SELLERS: THE CONTACT LENS INDUSTRY
}

\author{
Deborah Haas-Wilson*
}

\begin{abstract}
The asymmetric information characterizing markets for professional services has been used to justify tying requirements and other restrictions on the business practices of professionals. In this paper the prices and quality effects of state restrictions that prohibit the fitting of contact lenses by independent opticians and thereby tie the sale of contact lenses to the services of ophthalmologists and optometrists are estimated. The results suggest that prices are significantly higher in markets with tying requirements, controlling for differences in quality and variations in other state commercial practice re-
\end{abstract}

Received for publication December 12, 1985. Revision accepted for publication July $15,1986$.

* Smith College.

I would like to thank Mark Aldrich, Randy Bartlett, Roger Kaufman, and the anonymous referees for helpful comments. Also I would like to thank the U.S. Federal Trade Commission for providing part of the data base. strictions. The tying requirements and the commercial practice restrictions, however, appear to have statistically insignificant effects on quality.

While economists and the courts have focused on the questionable uses of tying requirements by sellers with market power in concentrated markets, questionable tying requirements are also observed in markets with many sellers. For example, a recent Federal Trade Commission (FTC) regulation prohibited funeral directors from tying the sale of caskets to the purchase of cremation services. ${ }^{1}$ A 1978 FTC regulation prohibited oph-

\footnotetext{
${ }^{1}$ Funeral Industry Practices, Trade Regulation Rule. 49 Fed. Reg. 3, 564 (1984).
} 
thalmologists and optometrists from requiring customers to purchase their eyeglasses from the same provider who conducted their eye examination. ${ }^{2}$ The FTC is also investigating state prohibitions on denturism, the practice of dental laboratory technicians selling dentures directly to the public without the involvement of a dentist. State prohibitions on denturism effectively tie the sale of dentures to the services provided by dentists (Kushman, 1983). In each of these cases, tying requirements are found in industries with many sellers. Yet in each of these industries sellers have some degree of market power as a result of licensing laws and imperfect consumer information.

This paper examines the effect of tying requirements on the prices and qualities of goods and services offered by sellers with some degree of market power in relatively unconcentrated markets. Accordingly, the analysis incorporates elements from the traditional commodity bundling literature which analyzes the use of tying requirements to increase the profits of monopolists (Bowman, 1957; Stigler, 1968; Adams and Yellen, 1976; and Schmalensee, 1982) and the more recent literature which analyzes the use of tying requirements by sellers in unconcentrated markets (Craswell, 1982). In particular, this paper presents an econometric study of the economic impact of state restrictions that prohibit the fitting of contact lenses by opticians, and thereby tie the sale of contact lenses to the services of ophthalmologists and optometrists.

Current regulatory policy toward opticians' scope of practice is based on the assumption that the market fails because (1) consumers are faced with the dilemma of selecting an ophthalmologist, optometrist, or optician without the benefit of full information on the quality of services provided and (2) opticians, in particular, may exploit this asymmetric information by providing lower quality services. This assumption has led to the inference that restricting opticians' ability to independently fit contact lenses is necessary to protect consumers from their own purchase decisions and from unfair seller behavior.

Although there is theoretical support for the argument that imperfect consumer information will result in market failure (Akerlof, 1970), an FTC study (1983) concluded that the difference between the quality of contact lens fittings by ophthalmologists, optometrists, and opticians is not statistically significant. This result suggests that state restrictions on contact lens fittings by opticians may not be necessary to protect consumers. The FTC, however, did not include tying requirements in their empirical analysis and thus did not test the effect of tying requirements on price or quality. In

\footnotetext{
${ }^{2}$ Advertising of Ophthalmic Goods and Services, Trade Regulation Rule, 43 Fed. Reg. 23, 992 (1978).
}

addition, the FTC did not control for variations in demand, production costs, state commercial practice restrictions, or state licensing requirements.

\section{Tying Requirements in the Market for Contact Lenses}

The traditional antitrust objection to tying requirements, the requirement that the purchaser of one product, the tying product, purchase a second, tied product from the same seller, is based on the assumption that sellers with market power in the tying good market will use tie-in sales to exclude competitors in the tied good market and thereby extend their market power into the tied good market. Economists, however, have questioned this "leverage" theory of tie-in sales. If the tying and tied goods are consumed jointly and in fixed proportions, then an increase in the price of the tied good will, ceteris paribus, decrease demand for the tied and the tying good. Rather, economists have suggested that monopolists may use tying requirements to increase profits through price discrimination (Bowman, 1957) or through strategies of pure and mixed bundling (Stigler, 1968, Adams and Yellen, 1976, and Schmalensee, 1982).

Tying requirements may have an exclusionary effect, however, if the tying and tied goods are complements and consumed in variable proportions (Bowman, 1957), the sale of the tied product for use with the tying product represents a substantial share of all sales of the tied product (Posner, 1976), or the purpose of the tying requirement is to protect the reputation of the seller of the tying good (Posner, 1976). Sellers may engage in tying to protect their reputations when consumers can evaluate the performance of the bundle but not the performance of the tying and tied good separately. Thus, the reputation of the tying good seller is not hurt by the use of low quality tied goods (Craswell, 1982).

This discussion suggests that the evaluation of the legality of tying requirements in the market for contact lenses should include an assessment of the effect of the tying requirement on both price and quality.

The purchase of contact lenses is a three step process. First, the consumer must go to an ophthalmologist or optometrist to obtain a refractive eye examination and contact lens perscription. Opticians are not allowed to prescribe contact lenses. Then the potential contact lens consumer requires a keratometric or fitting examination to measure the radius of curvature of the cornea. Finally the lenses must be purchased and their fit evaluated.

In twenty-two states tying requirements between the refractive eye examination or contact lens prescription and the contact lenses are imposed indirectly by laws which prohibit the fitting of contact lenses by independent opticians (opticians practicing independently from 
optometrists or ophthalmologists). The laws in four of these states ${ }^{3}$ prohibit the fitting of contact lenses by any optician. In sixteen states $^{4}$ the laws permit opticians to fit contact lenses, but only under the supervision of ophthalmologists and optometrists. In Alabama, Florida, and the District of Columbia opticians may dispense contact lenses, but only with a prescription that includes both refractive test information and post-refractive eye measurements.

\section{The Model and Empiricai Results}

Following a symmetric oligopoly model developed by Cubbin (1974) and extended by Waterson (1984), sellers producing a heterogeneous product are assumed to maximize profits with respect to price. Thus, each seller will have a profit function:

$$
\Pi_{j}=p_{j} q_{j}-C_{j}\left(q_{j}\right) \quad j=1,2, \ldots, N
$$

where $q_{j}=f_{j}\left(p_{1}, p_{2}, \ldots, p_{N}\right)$. Accordingly, ophthalmic supplier $_{j}$ sets price to satisfy:

$$
P_{j}=C_{j}^{\prime}\left[1-\left(1 /\left(\alpha E+(1-\alpha) e_{j}\right)\right)\right]^{-1}
$$

where

$$
\alpha=\frac{\left[\sum_{i \neq j}\left(d p_{i} / d p_{j}\right)\left(\partial q_{j} / \partial p_{i}\right)\right]}{\sum_{i \neq j} \partial q_{j} / \partial p_{i}}
$$

$P_{j}$ is a function of supplier ${ }_{j}$ 's marginal costs $C_{j}^{\prime}$, the weighted average of sellers' conjectural variations with respect to price $\alpha$, the market elasticity of demand when $d p_{i} / d p_{j} \equiv 1, E$, and seller ${ }_{j}$ 's elasticity of demand when $d p_{i} / d p_{j} \equiv 0, e_{j}$.

The determinants of $C_{j}^{\prime}$ are the prices of inputs (INPUT), the implicit price of seller ${ }_{j}$ 's own time, and the type of contact lenses supplied (SOFT). The implicit price of a seller's time depends on the number of hours worked and seller type-whether the seller who fit the contact lenses is an ophthalmologist, optometrist, or optician $\left(F I T-O P T Y P E_{j}\right)$ and whether the seller who provided the refractive eye exam is an ophthalmologist or optometrist ( $\left.E X-O P T Y P E_{j}\right)$. As a seller works longer hours, the value of his/her time increases. Hours worked will depend on both the quality of services provided $\left(Q U A L I T Y_{j}\right)$ and demand for services (measured as per capita income $Y$ ) relative to the number of sellers $(N)$. Assuming higher quality lens fittings require more labor time, marginal costs will increase as quality increases. Assuming sellers work longer hours when demand increases, marginal costs will increase as $Y$ increases

\footnotetext{
${ }^{3}$ Missouri, New Jersey, New Mexico, and Vermont.

${ }^{4}$ Alaska, California, Colorado, Deleware, Florida, Hawaii, Illinois, Kentucky, Mississippi, Nevada, New York, Oregon, South Carolina, Tennessee, Texas, and Virginia.
}

relative to $N$. The implicit price of sellers' time will vary by seller type due to differences in ophthalmologists', optometrists', and opticians' investments in education and abilities to realize economies of scale and scope.

Sellers' conjectural variations with respect to price will depend on the extent to which competitors' abilities to compete are constrained. Sellers practicing in states with restrictions on the business practices of optometrists ( $R E G$ and $R-A D)$ and opticians ( $R-F I T)$ may believe $d p_{i} / d p_{j}$ is closer to zero. $R E G$ includes restrictions on (1) the use of trade names, (2) the employment of optometrists by lay persons or corporations, (3) the number of branch offices an optometrist may operate, and (4) locating offices in mercantile locations. $R-F I T$ and $R-A D$ are state restrictions on contact lens fittings by opticians and advertising, respectively.

$E$ and $e_{j}$ depend on the level of consumer information which in turn depends on the number of sellers (Pauly and Satterthwaite, 1981) and the level of advertising (Nelson, 1974). The level of advertising chosen by supplier ${ }_{j}$ is assumed to be a function of $P_{j}$ and $Q U A L$ $I T Y_{j}$ (Nelson, 1974 and Kihlstrom and Riordan, 1984), supplier type, ${ }^{5}$ and $R-A D$ :

$$
\begin{array}{r}
A_{j}=g_{j}\left(P_{j}, Q U A L I T Y_{j}, F I T-O P T Y P E_{j},\right. \\
\left.E X-O P T Y P E_{j}, R-A D\right) .
\end{array}
$$

The number of ophthalmic suppliers depends on market profitability or demand, measured as $Y$ (Newhouse, Williams, Schwartz, Bennett, 1982), state licensure requirements (Benham, Maurizi, and Reder, 1968), and the regulatory environment (Meltzer, Langwell, Keane, and Nelson, 1983):

$$
N=b(Y, R E G, R-A D, R-F I T, L I C) \text {. }
$$

State restrictions on the business practices of optometrists may deter entry by optometrists. And as discussed earlier, $R-F I T$ may have an exclusionary effect on opticians. Further it is expected that fewer opticians will locate in the twenty-one states that require their licensure $(L I C)$.

Equations (2) through (4) can be solved implicitly for $P_{j}$ as a function of the variables on which $C_{j}^{\prime}, \alpha, E, e_{j}$, $\boldsymbol{A}_{j}$, and $N$ depend:

$$
\begin{aligned}
P_{j}=h_{j} & (\text { QUALITY }, R-F I T, R E G, R-A D, \\
& L I C, F I T-O P T Y P E_{j}, E X-O P T Y P E_{j}, \\
& \left.\operatorname{SOFT}_{j}, I N P U T, Y\right) .
\end{aligned}
$$

To test the effect of state contact lens fitting restrictions on the quality of contact lens fittings, an expanded version of the FTC's (1983) regression model is estimated. The FTC's model included (1) contact lens

\footnotetext{
${ }^{5}$ Approximately $74 \%$ of opticians, $45 \%$ of optometrists, and $32 \%$ of ophthalmologists choose to advertise. 20/20 Magazine (Nov./Dec. 1985), p. 86.
} 
wearer characteristics that may influence quality of fit (WEARER), such as age, sex, wearing time prior to the FTC exam, and average hours worn per day, (2) lens characteristics that may influence fit quality ( $L E N S)$, such as type, cleanliness, damage, and warpage, and (3) the type of supplier who fit the contact lens.

The FTC's quality model is expanded to include the package price of the contact lenses because suppliers are assumed to choose price and quality jointly. Further the FTC's model is expanded to include a measure of the difficulty of fitting contact lenses for a particular consumer $(F A I L)$, and the four state regulatory variables:

$$
\begin{aligned}
\text { QUALITY }_{j}=a_{j}( & \text { WEARER }_{j}, L E N S_{j}, \\
& \text { FIT-OPTYPE } \\
& , P_{j}, F A I L_{j}, \\
& R-F I T, R-A D, L I C, R E G) .
\end{aligned}
$$

FAIL equals one if the consumer tried to wear contact lenses before, but was unsuccessful, and zero otherwise. As the degree of difficulty of fitting the contact lenses increases, quality of the contact lens fitting may decrease. State commercial practice restrictions and licensing requirements may increase the level of quality. ${ }^{6}$

$Q U A L I T Y_{j}$ and $P_{j}$ are endogenous. Accordingly, the effects of state tying requirements on quality and price are estimated using two stage least squares regression (2SLS).

The FTC data include the price and quality of the contact lenses provided by a sample of 354 ophthalmologists, optometrists, and opticians between 1976 and 1979 in 18 urban areas. Quality is measured as an index of the contact lens wearer's eye health or the relative presence of seven potentially pathological eye conditions caused by poorly fitted contact lenses. Price is measured as the adjusted package price of the eye examination, keratometric examination, and the contact lenses. ${ }^{7}$ These data are described in more detail in FTC (Dec. 1983).

\section{The Empirical Results}

The results of regressions that test the effect of state tying requirements on contact lens prices, controlling for differences in quality are reported in table $1 .{ }^{8}$ Using the linear and log-linear form the null hypothesis that the coefficient on $R-F I T$ is equal to zero can be rejected

\footnotetext{
${ }^{6}$ Federal Trade Commission (Sept. 1980).

7 " The contact lens package price charged to each subject was deflated by a cost of living index derived from a Bureau of Labor Statistics survey of family budgets for 39 cities. Indices were keyed to both the city of fit and year of fit." FTC, Dec. 1983, at C-3.

${ }^{8}$ The reported regressions use $Q U A L W$ as the measure of fit quality. Estimation of equation (5) using $Q U A L U$ gives similar results.
}

TABLE 1.-2SLS Regressions ON PRICE (standard errors in parentheses) $^{\mathrm{a}}$

\begin{tabular}{lcc}
\hline & $P R I C E$ & $\ln (P R I C E)$ \\
\hline CONSTANT & $167.30^{\mathrm{f}}$ & $7.07^{\mathrm{f}}$ \\
SOFT & $(43.29)$ & $(1.65)$ \\
& $53.92^{\mathrm{f}}$ & $0.31^{\mathrm{f}}$ \\
FITOPH & $(6.48)$ & $(0.04)$ \\
& $17.87^{\mathrm{d}}$ & 0.10 \\
FITOPTOM & $(10.84)$ & $(0.07)$ \\
& 2.72 & 0.00 \\
EXOPH & $(13.93)$ & $(0.09)$ \\
& $28.48^{\mathrm{e}}$ & $0.15^{\mathrm{d}}$ \\
$Y^{\mathrm{b}}$ & $(13.77)$ & $(0.09)$ \\
& -0.01 & -0.24 \\
INPUT & $(0.00)$ & $(0.20)$ \\
& -18.52 & -0.19 \\
QUALW & $(39.06)$ & $(0.24)$ \\
& -0.64 & 0.00 \\
$R-F I T$ & $(0.88)$ & $(0.01)$ \\
& $17.29^{\mathrm{e}}$ & $0.08^{\mathrm{d}}$ \\
LIC & $(7.85)$ & $(0.05)$ \\
& -4.45 & 0.02 \\
$R-A D$ & $(7.33)$ & $(0.05)$ \\
REG & $22.89^{\mathrm{d}}$ & 0.10 \\
& $(13.29)$ & $(0.08)$ \\
& $9.14^{\mathrm{f}}$ & $0.04^{\mathrm{e}}$ \\
& $(3.07)$ & $(0.02)$ \\
& $N=354$ & $N=354$ \\
& $R^{2}=0.29$ & $R^{2}=0.26$ \\
& $F=12.73$ & $F=10.98$ \\
\hline
\end{tabular}

${ }^{a}$ Estimated standard errors adjusted as suggested by Maddala (1977) at 239.

${ }^{b} \operatorname{Ln}(Y)$ for the log-linear regression.

c Predicted values.

d Significant at the $10 \%$ level of significance

e Significant at the $5 \%$ level of significance.

I Significant at the $1 \%$ level of significance.

at the $5 \%$ and the $10 \%$ levels of significance, respectively. The results suggest that contact lens prices are approximately $\$ 17.30$ or $8 \%$ higher in states with the contact lens fitting restriction. With respect to the relationship between price and quality, the results suggest that quality, measured as eye health, does not have a statistically significant effect on price.

Restrictions on the commercial-practices of optometrists are also associated with higher contact lens prices, controlling for quality differences in both regressions. This is consistent with an earlier study that found eyeglass prices are higher in states with commercial practice restrictions (Haas-Wilson, 1986). State licensing requirements for opticians and the advertising restriction, however, have statistically insignificant effects on contact lens prices. Earlier studies found that eyeglass prices were higher in states with advertising restrictions (Benham, 1972; Feldman and Begun, 1978). The difference may be due to the fact that the earlier studies did not control for the presence of other commercial practice restrictions. 
TABLE 2.-2SLS REGRESSION ON QUALITY (standard errors in parentheses) $^{\mathrm{a}}$

\begin{tabular}{|c|c|c|}
\hline & $Q U A L W$ & $Q U A L U$ \\
\hline CONSTANT & $\begin{array}{c}8.02 \\
(9.08)\end{array}$ & $\begin{array}{c}2.04 \\
(3.45)\end{array}$ \\
\hline FITOPH & $\begin{array}{c}3.39 \\
(2.68)\end{array}$ & $\begin{array}{c}1.17 \\
(1.02)\end{array}$ \\
\hline FITOРТОМ & $\begin{array}{c}-0.06 \\
(2.01)\end{array}$ & $\begin{array}{c}0.11 \\
(0.77)\end{array}$ \\
\hline$P^{\mathrm{b}}$ & $\begin{array}{c}-0.08 \\
(0.07)\end{array}$ & $\begin{array}{c}-0.03 \\
(0.03)\end{array}$ \\
\hline$S E X$ & $\begin{array}{r}3.61^{\mathrm{d}} \\
(1.57)\end{array}$ & $\begin{array}{r}1.23^{\mathrm{d}} \\
(0.60)\end{array}$ \\
\hline$A G E$ & $\begin{array}{c}-0.07 \\
(0.07)\end{array}$ & $\begin{array}{r}-0.03 \\
(0.03)\end{array}$ \\
\hline$F A I L$ & $\begin{array}{c}-2.83 \\
(1.91)\end{array}$ & $\begin{array}{r}-1.04 \\
(0.73)\end{array}$ \\
\hline$W E A R T I M E$ & $\begin{array}{r}-0.83^{\mathrm{e}} \\
(0.29)\end{array}$ & $\begin{array}{r}-0.31^{\mathrm{e}} \\
(0.11)\end{array}$ \\
\hline HOURS & $\begin{array}{r}-0.83^{\mathrm{c}} \\
(0.47)\end{array}$ & $\begin{array}{r}-0.29^{c} \\
(0.18)\end{array}$ \\
\hline$D I R T$ & $\begin{array}{r}-1.65^{\mathrm{c}} \\
(1.03)\end{array}$ & $\begin{array}{r}-0.56 \\
(0.39)\end{array}$ \\
\hline$D A M A G E$ & $\begin{array}{c}1.03 \\
(0.87)\end{array}$ & $\begin{array}{c}0.38 \\
(0.33)\end{array}$ \\
\hline$W A R P$ & $\begin{array}{c}0.07 \\
(1.09)\end{array}$ & $\begin{array}{r}-0.17 \\
(0.41)\end{array}$ \\
\hline SOFT & $\begin{array}{r}7.85^{d} \\
(4.10)\end{array}$ & $\begin{array}{r}2.71^{c} \\
(1.56)\end{array}$ \\
\hline$R-F I T$ & $\begin{array}{r}-0.10 \\
(1.46)\end{array}$ & $\begin{array}{c}-0.18 \\
(0.55)\end{array}$ \\
\hline$R-A D$ & $\begin{array}{c}0.06 \\
(2.30)\end{array}$ & $\begin{array}{r}-0.48 \\
(0.87)\end{array}$ \\
\hline$L I C$ & $\begin{array}{c}-0.53 \\
(1.31)\end{array}$ & $\begin{array}{c}-0.19 \\
(0.50)\end{array}$ \\
\hline$R E G$ & $\begin{array}{c}0.53 \\
(0.67)\end{array}$ & $\begin{array}{c}-0.01 \\
(0.26)\end{array}$ \\
\hline & $N=354$ & $N=354$ \\
\hline & $\begin{aligned} R^{2} & =0.14 \\
F & =3.51\end{aligned}$ & $\begin{aligned} R^{2} & =0.14 \\
F & =3.29\end{aligned}$ \\
\hline
\end{tabular}

${ }^{239}$ Esti.

b Predicted values.

c Significant at the $10 \%$ level of significance.

d Significant at the $5 \%$ level of significance.

e Significant at the $1 \%$ level of significance.

Equation (6) is estimated in linear form using two measures of quality - a weighted index of eye health $(Q U A L W)$ and an unweighted index of eye health $(Q U A L U){ }^{9}$ The results in table 2 suggest that state tying requirements in the market for contact lenses have a statistically insignificant effect on fit quality. Further it appears the quality provided by opticians is not significantly different than that provided by optometrists or ophthalmologists. This is consistent with the FTC's

\footnotetext{
${ }^{9}$ The quality regressions were also estimated separately for soft and hard contact lenses. This changed the significance of some of the WEARER and LENS variables; however, it did not change the significance of any of the regulatory variables.
}

(1983) finding. Finally, the results suggest that advertising restrictions, commercial practice restrictions, and opticians' licensing requirements have statistically insignificant effects on quality.

\section{Conclusions}

While a large body of empirical evidence exists on the effects of advertising and other commercial practice restrictions in the market for eyeglasses, this is the first study of the effects of tying requirements and commercial practice restrictions in the market for contact lenses. The results suggest that state restrictions which effectively tie the sale of contact lenses to eye examinations by prohibiting opticians from independently fitting contact lenses increase the total price of contact lenses by approximately $8 \%$, controlling for differences in quality and variations in other state restrictions. This in combination with the finding that state contact lens fitting restrictions have a statistically insignificant effect on quality suggests that the restrictions are benefiting providers rather than consumers of contact lenses.

\section{REFERENCES}

Adams, William, and Janet Yellen, "Commodity Bundling and the Burden of Monopoly," Quarterly Journal of Economics 90 (Aug. 1976), 475-498.

Akerlof, George, "The Market for 'Lemons': Quality Uncertainty and the Market Mechanism," Quarterly Journal of Economics 84 (Aug. 1970), 488-500.

Benham, Lee, "The Effect of Advertising on the Price of Eyeglasses," Journal of Law and Economics 15 (Oct. 1972), 337-352.

Benham, Lee, A. Maurizi, and M. Reder, “Migration, Location and Remuneration of Medical Personnel: Physicians and Dentists," this REVIEW 50 (Aug. 1968), 332-347.

Bowman, Ward, "Tying Arrangements and the Leverage Problem," Yale Law Journal 67 (Nov. 1957), 19-36.

Craswell, Richard, "Tying Requirements in Competitive Markets: The Consumer Protection Issues," Boston University Law Review 62 (1982), 661-700.

Cubbin, J., "A Measure of Apparent Collusion in Oligopoly," Warwick Economic Research Paper no. 49 (1974).

Federal Trade Commission, A Comparative Analysis of Cosmetic Contact Lens Fitting by Ophthalmologists, Optometrists, and Opticians (Dec. 1983).

, Effects of Restrictions on Advertising and Commercial Practice in the Professions: The Case of Optometry (Sept. 1980).

Feldman, R., and J. Begun, "The Effects of Advertising: Lessons from Optometry," Journal of Human Resources 13 (Supplement 1978), 247-262.

Haas-Wilson, Deborah, "The Effect of Commercial Practice Restrictions: The Case of Optometry," Journal of Law and Economics 29 (Apr. 1986), 165-186.

Kihlstrom, R., and M. Riordan, "Advertising as a Signal," Journal of Political Economy 92 (1984), 427-450.

Kushman, John, "Conceptual Foundations for Policy Analysis of Unbundling Health Services," presented to the Atlantic Economic Society, Philadelphia, Oct. 1983.

Maddala, G. S., Econometrics (New York: McGraw-Hill Book Company, 1977). 
Meltzer, Alfred, Kathryn Langwell, Michael Keane, and Shelly Nelson, Report on the Geographic Distribution of Vision Care Providers (Silver Spring, Maryland: Applied Management Sciences, Inc., 1983).

Nelson, Phillip, "Advertising as Information," Journal of Political Economy 81 (July/Aug. 1974), 729-754.

Newhouse, Joseph, Albert Williams, William Schwartz, and Bruce Bennett, "The Geographic Distribution of Physicians: Is the Conventional Wisdom Correct?" Rand (Oct. 1982).

Office of Technology Assessment, The Contact Lens Industry: Structure, Competition, and Public Policy, Health Technology Case Study 31, Dec. 1984.
Pauly, Mark, and Mark Satterthwaite, "The Pricing of Primary Care Physicians' Services: A Test of the Role of Consumer Information," Bell Journal of Economics 12 (Autumn 1981), 488-506.

Posner, Richard, Antitrust Law-An Economic Perspective (Chicago: University of Chicago Press, 1976).

Schmalensee, Richard, "Commodity Bundling by Single-Product Monopolies," Journal of Law and Economics 25 (Apr. 1982), 67-71.

Stigler, George, "A Note on Block Booking," in The Organization of Industry (Homewood: R. D. Irwin, 1968).

Waterson, Michael, Economic Theory of the Industry (Cambridge: Cambridge University Press, 1984).

\title{
SHEEPSKIN EFFECTS IN THE RETURNS TO EDUCATION
}

\author{
Thomas Hungerford and Gary Solon*
}

\begin{abstract}
Some previous discussions have dismissed screening theories of education partly on the ground that diploma years of education do not confer especially large earnings gains. Similarly, most empirical research on earnings functions has assumed an absence of "sheepskin" effects. We report evidence, however, of substantial and statistically significant sheepskin effects. Although this suggests that the previous dismissals of the screening hypothesis were premature, our evidence of sheepskin effects is amenable to nonscreening interpretations also.
\end{abstract}

According to screening theories of education, individuals with more schooling tend to earn more not because (or, at least, not solely because) schooling makes them more productive, but rather because it credentiates them as more productive. A frequently cited article by Layard and Psacharopoulos (1974), however, dismissed the importance of the screening hypothesis on the grounds that several of its refutable predictions were not supported by available evidence. One of these was the "sheepskin" prediction that "wages will rise faster with extra years of education when the extra year also conveys a certificate." After surveying a number of studies, Layard and Psacharopoulous (henceforth LP) concluded that "rates of return to dropouts are as high as to those who complete a course, which refutes the sheepskin version of the screening hypothesis."

Since publication of the LP paper, an undergraduate labor economics textbook ${ }^{1}$ has cited LP's analysis of sheepskin effects as "telling criticism" of the screening

Received for publication March 6, 1986. Revision accepted for publication July 8, 1986.

* The University of Michigan.

The authors thank Charles Brown and the referees for their comments.

${ }^{1}$ Addison and Siebert (1979, p. 139). hypothesis. A prominent proponent of the screening hypothesis, Riley (1979), has accepted LP's summary of the empirical evidence, but responded that some versions of the screening hypothesis do not imply sheepskin effects. In the meantime, the ongoing flood of empirical research on earnings functions typically has continued to treat the natural logarithm of the wage rate as a linear (or occasionally quadratic) function of years of education, with no allowance for discontinuities in diploma years. ${ }^{2}$

The estimated rates of return used by LP were based on data that did not disaggregate dropouts' earnings by how many years of school they had completed. LP acknowledged, "We would have preferred to show the earnings gain associated with each year of the course, including the year when it was successfully completed." This note presents a reanalysis of sheepskin effects based on the type of data LP wished they had. The results contain very strong evidence of sheepskin effects after all. The next section describes our analysis, and the following section summarizes and discusses our results.

\section{Empirical Analysis}

Our analysis is based on May 1978 Current Population Survey data on white male nonagricultural wage and salary workers between the ages of 25 and 64 . The uncommonly large sample size in this data set $(16,498$ observations) enables relatively precise estimation of nonlinear returns to education.

\footnotetext{
2 There have been occasional exceptions, however, such as Goodman (1979), Mohan (1981), Olneck (1979), and Weiss (1984).
} 